\title{
Strategi Lembaga Amil ZIS Muhammadiyah dalam Mencadapatkan Kepercayaan Muzakki
}

\author{
Rita Cantika ${ }^{1 *}$, Arif Rahman $1^{1}$, Herman $2^{2}$ \\ 123Jurusan Manajemen Dakwah, Fakultas Dakwah dan Komunikasi, UIN Sunan Gunung Djati, \\ Bandung \\ *Email : rita.cantika.fidkom@gmail.com
}

\begin{abstract}
ABSTRAK
Penelitian ini bertujuan untuk mengetahui perencanaan, kebijakan dan strategi yang digunakan Lembaga Amil Zakat Infaq dan Shadaqah Muhammadiyah (LAZISMU) Cabang Cibiuk dalam upaya mendapatkan kepercayaan muzakki. Dalam rangka menjawab permasalahan sebagai berikut: bagaimana penyusunan perencanaan, penetapan kebijakan yang dijadikan garis pedoman dan bagaimana strategi yang dirancang oleh Lembaga Amil Zakat Infaq dan Shadaqah Muhammadiyah Cibiuk dalam mendapatkan kepercayaan muzakki. Penelitian ini menggunakan metode deskriptif dengan teknik pengumpulan data dihimpun melalui teknik observasi, wawancara, studi dokumentasi, analisis data dan penyimpulan. Penelitian ini menunjukkan bahwa strategi Lembaga Amil Zakat Infaq dan Shadaqah Muhammadiyah (LAZISMU) Cabang Cibiuk dalam mendapatkan kepercayaan muzakki atau donatur secara garis besar 1) Perencanaan ZIS yang direncanakan bisa berhasil dengan baik dari pengumpulan, pengelolaan dan pendistribusian yang telah direncanakan melalui program LAZISMU, 2) Penetapan kebijakan yaitu pembentukan kordinator penghimpun zakat di setiap Ranting, penerbitan surat keputusan $40 \%$ hak cabang dan $60 \%$ hak ranting, serta mewajibkan setiap anggota organisasi membayar zakat ke LAZISMU dapat terealisasi, 3) Strategi di Lembaga Amil Zakat Infaq dan Shadaqah Muhammadiyah adalah realized strategic (strategi yang direalisasikan). menjalankan 8 strategi yang direalisasikan dari 13 strategi yang dikehendaki melalui programnya.
\end{abstract}

Kata Kunci: Strategi; Kepercayaan; dan Muzakki;

\section{ABSTRACT}

This study aims to determine the planning, policies and strategies used by the Cibiuk Branch Amada Zakat Infaq and Shadaqah Mubammadiyah (LAZISMU) in an effort to get the 
muzake. i trust. In order to answer the problem as follow: how to plan, determine policies that are used as guidelines and how the strategy designed by the Amil Zakat Infaq and Shadaqah Muhammadiyah Cibiuk in obtaining muzakei trust. This research uses descriptive method with data collection techniques collected through observation, interview, documentation study, data analysis and conclusion techniques. This study shows that the strategy of the Cibiuk Branch of the Zakat Infaq Amil and Shadaqah Mubammadiyah institute (LAZISMU) in gaining the trust of mualkei or donors in general 1) The planned ZIS planning can succeed well from the collection, management and distribution planned through the LAZISMU program, 2) Determination of policies, namely the establishment of zakat collecting coordinators in each branch, issuance of $40 \%$ branch rights and $60 \%$ branching rights, and requiring every organization member to pay zakat to LAZISMU to be realized strategic. 3) Run 8 strategies realized from the 13 strategies desired through the program.

Keywords: Strategy; Trust; and Muzakki;

\section{PENDAHULUAN}

Lembaga Amil Zakat Infaq dan Shadaqah Muhammadiyah Cabang Cibiuk adalah lembaga yang secara struktural berada dibawah Pimpinan Cabang Muhammadiyah Cibiuk serta merupakan salah satu lembaga yang berada di Kecamatan Cibiuk Kabupaten Garut. Perkembangannya dinilai cukup pesat. Terhitung sejak berdiri pada tanggal 27 November 2011 bertempat sekretariat di Jl. Raya Cibiuk No.1 Desa Cibiuk Kaler Kecamatan Cibiuk Kabupaten Garut. Kini LAZISMU Cibiuk telah menjadi pusat pengumpulan zakat, infaq dan shadaqah masyarakat Muhammadiyah di Kecamatan Cibiuk. LAZISMU Cibiuk menjadi salah satu wadah yang memiliki tugas sebagai fasilitator dalam membangun iklim keagamaan yang kondusif, mewujudkan kondisi masyarakat yang sejahtera, makmur, toleran dan saling tolong menolong terhadap sesama melalui kegiatan penghimpunan, pendistribusian, maupun pendayagunaan zakat infaq dan shadaqah. Dalam proses strategi penghimpunan zakat LAZISMU Cibiuk, yaitu suatu upaya atau proses kegiatan dalam rangka menghimpun dana zakat, infaq dan shadaqah dari masyarakat baik individu, kelompok organisasi, dan perusahaan yang akan disalurkan dan didayagunakan untuk orang yang berhak menerima zakat (mustahik). Maka dalam hal ini butuh strategi yang mapan agar terkumpul secara maksimal. (Direktorat Pemberdayaan Zakat Dirjen Bimbingan Masyarakat Islam Kementrian Agama Republik Indonesia, 2009: 65). Dalam artian sederhana yaitu upaya yang dilakukan untuk membangun kepercayaan menyalurkan zakat pada lembaga zakat. Maka berpijak dari fenomena ini penulis bermaksud menjadikan strategi LAZISMU Cibiuk ini sebagai objek penelitian skripsi.

Teori yang dikemukakan oleh Glueck William F. dan Jauch Lawrence R. Sebuah rencana yang disatukan, luas dan terintegrasi, yang menghubungkan keunggulan strategi perusahaan dengan tantangan lingkungan dan yang 
dirancang untuk memastikan bahwa tujuan utama perusahaan dapat dicapai melalui pelaksanaan yang tepat oleh organisasi. (Saladin, 2010: 1) Dari pengertian tersebut, dapatlah disimpulkan bahwa strategik perusahaan adalah suatu kesatuan, rencana yang menyeluruh, komprehensif, dan terpadu yang diarahkan untuk mencapai tujuan perusahaan. Menurut Dess Gregory G dan Miller Alex "Manajemen strategik adalah suatu proses kombinasi antara tiga aktivitas, yaitu analisis strategik, perumusan strategik, dan implementasi strategik". (Djaslim Saladin, 2010:4).Penerapan strategi sering kali disebut "tahap aksi" dari manajemen strategis. Menerapkan strategi berarti memobilisasi karyawan dan manajer untuk melaksanakan strategi yang telah dirumuskan.Sering kali dianggap sebagai tahap yang paling sulit dalam manajemen strategis, penerapan atau implementasi strategi membutuhkan disiplin, komitmen, dan pengorbanan personal. Penerapan strategi yang berhasil bergantung pada kemampuan manajer untuk memotivasi karyawan, yang lebih merupakan seni daripada pengetahuan. Strategi tersebut dirumuskan, namun bila tidak diterapkan tidak ada gunanya (Fred, 2011: 7). Ada beberapa hal yang dapat ditarik kesimpulan dari pengertian strategik di atas, yaitu: 1) Adanya suatu rencana tindakan yang dirancang untuk mencapai tujuan bukan hanya tujuan jangka pendek, akan tetapi juga tujuan jangka menengah dan jangka panjang, 2) Untuk menyusun suatu strategik, diperlukan analisis terhadap lingkungan, baik lingkungan eksternal maupun lingkungan internal, yaitu peluang dan ancaman/tantangan maupun kekuatan dan kelemahan perusahaan. Hal ini penting untuk mengantisipasi perubahanperubahan yang terjadi, 3) Perlunya suatu keputusan pilihan dan pelaksanaan yang tepat dan terarah guna mencapai tujuan perusahaan. 4) Strategik dirancang untuk menjamin agar tujuan dan sasaran dapat dicapai melalui langkah-langkah yang tepat (Saladin, 2010: 2).

Penelitian ini dilaksanakan di Lembaga Amil Zakat Infaq dan Shadaqah Muhammadiyah (LAZISMU) Cibiuk yang terletak di Jl. Raya Cibiuk No.1 Desa Cibiuk Kaler Kecamatan Cibiuk Kabupaten Garut.

Berikut pertanyaan penelitian yang diajukan pada pimpinan, sekretaris dan para staff Lembaga Amil Zakat Infaq dan Shadaqah Muhammadiyah (LAZISMU) Cibiuk untuk menjawab fokus penelitian : 1) Sejarah dan latar belakang LAZISMU?, 2) Strategi dalam mendapatkan muzakki LAZISMU?, 3) Segi kualitas pelayanan, bagaimana upaya peningkatan pemberian kualitas pelayanan?, 4) Segi responsivitas, bagaimana respon dari lembaga terhadap kritik/keluhan atau saran dari muzakki dan mustahik?, 5) Segi responsibilitas, bagaimana upaya yang dilakukan agar LAZISMU berpedoman sesuai dengan ketentuan syari'ah dan Undang-Undang pengelolaa zakat?, 6) Segi akuntabilitas, bagaimana bentuk laporan pengelolaan zakat yang diberikan pada khalayak agar LAZISMU mendapatkan kepercayaan?, 7) Segi profesionalitas, apa upaya yang dilakukan untuk meningkatkan kinera para internal lembaga (karyawan)?, 8) 
Program apa saja yang diberikan pada muzakki atau donator?, 9) Adakah fasilitas yang memberikan kemudahan para muzaki atau donator untuk berzakat?, 9) Apa saja yang menjadi media yang digunakan lembaga untuk marketing zakat?, 10) Bagaimana letak geografis yang dijadikan lokasi lembaga marketing zakat?, 11) Adakah program unggulan yang ditawarkan setiap bulan tertentu?, 12) Bagaimana pengelolaan program pendayagunaan zakat yang ada di LAZISMU?, 13) Bagaimana tingkat keberhasilan strategi pendayagunaan yang telah dilakukan LAZISMU?, 14) Kendala serta solusi yang dilakukan dalam menjalankan program-program yang berjalan?.

Metode Penelitian pada penyusunan penelitian ini, penulis mengunakan pendekatan kualitatif yaitu dengan melakukan penelitian yang menghasilkan data deskriptif berupa kata-kata tertulis atau lisan dari orang-orang dan perilaku yang diamati. Penelitian deskriptif kualitatif ini diajukan untuk 1) mengumpulkan informasi aktual secara rinci yang melukiskan gejala yang ada dilokasi penelitian, 2) mengidentifikasi masalah atau memeriksa kondisi dan kegiatan yang ada dilokasi penelitian, 3) membuat perbandingan atau evaluasi, 4) menentukan apa yang dilakukan orang lain dalam menghadapi masalah yang sama dan belajar dari pengalaman mereka serta menentukan dan menetapkan rencana dan keputusan dalam memecahkan suatu masalah pada waktu yang akan datang.

\section{LANDASAN TEORITIS}

Fokus pembahasan dan analisis mengenai Strategi Lembaga Amil Zakat Infaq dan Shadaqah Muhammadiyah dalam Mendapatkan Kepercayaan Muzakki. Oleh karena itu, kajian teori yang dideskripsikan dalam kerangka berfikir ini difokuskan pada teori-teori tentang srategi, kepercayaan dan muzakki.

Strategi yang terdapat pada suatu lembaga ataupun di perusahaan dapat menjadi solusi untuk mengurangi ketidakpastian pada saat menyusun rencana serta mengurangi kegagalan yang terjadi dari suatu perencanaan di lingkungan perusahaan.

Kata 'strategi' berasal dari bahasa Yunani "strategos" yang berarti jenderal atau panglima, sehingga startegi diartikan sebagai ilmu kejenderalan atau ilmu kepanglimaan. Strategi dalam pengertian kemiliteran ini berarti cara penggunaan seluruh kekuatan militer untuk mencapai tujuan perang (Gulo, 2008: 1).

Menurut Glueck William F. dan Lawrence R. Strategik adalah sebuah rencana yang disatukan, luas dan terintegrasi, yang menghubungkan keunggulan strategik perusahaan dengan tantangan lingkungan yang dirancang untuk memastikan bahwa tujuan utama perusahaan dapat dicapai melalui pelaksanaan yang tepat oleh organisasi (Saladin, 2010: 1).

Sammy Kristamuljana, arti "strategi” adalah: "Tujuan bertahan hidup dan cara yang paling berdaya saing dalam mewujudkan tujuan itu". "berdaya saing" artinya, belum ada tujuan dan cara semacamnya yang lebih baik. 
Stephanie K. Marrus, strategi didefinisikan sebagai suatu proses penentuan rencana Para Pemimpin puncak yang berfokus pada tujuan jangka panjang organisasi, disertai penyusunan suatu cara atau upaya bagaimana agar tujuan tersebut dapat dicapai (Umar, 2001: 31).

Hamel dan Prahalad, strategi merupakan tindakan yang bersifat incremental (senantiasa meningkat) dan terus-menerus, serta dilakukan berdasarkan sudut pandang tentang apa yang diharapkan oleh para pelanggan di masa depan. Dengan demikian, strategi hampir selalu dimulai dari apa yang dapat terjadi dan bukan dimulai dari apa yang terjadi. Terjadinya kecepatan inovasi pasar yang baru perubahan pola konsumen memerlukan kompetensi inti di dalam bisnis yang dilakukan (Umar, 2001: 31).

Syaiful Bahri dan Aswan Zain mengemukakan pengertian strategi secara umum merupakan "suatu garis-garis besar haluan untuk bertindak dalam usaha mencapai sasaran yang telah ditentukan” (Djamarah dan Zain, 2006: 5).

Menurut Whelen dan Hunger, ada beberapa tingkatan dalam strategi untuk perusahaan besar. Ada tiga tingkatan strategi manajemen yang berkembang sesuai dengan perkembangan perusahaan yaitu: Strategi korporasi (Corporate strategy) Ini adalah strategi yang mencerminkan arah perusahaan yang bertujuan menciptakan pertumbuhan bagi perusahaan secara keseluruhan dan bagi manajemen berbagai macam bisnis lini produk. Strategi Bisnis (Business Strategy) strategi ini digunakan pada tingkat produk atau unit bisnis dan merupakan strategi yang menekankan pada perbankan posisi bersaing produk atau jasa pada spesifikasi atau segmen pasar tertentu. Strategi Fungsional (Fungsional Strategy) strategi ini digunakan pada level fungsional, pemasaran, keuangan, dan sumber daya manusia. Strategi ini mengacu pada dua tingkatan startegi sebelumnya yaitu strategi korporasi dan strategi bisnis.Strategi fungsional juga disebut sebagai value-based-strategy. Berfokus pada memaksimumkan produktivitas sumber daya yang digunakan dalam memberikan value terbaik untuk pemenuhan kebutuhan pelanggan (Saladin, 2010: 15).

Perencanaan secara garis besar diartikan sebagai proses mendefinisikan tujuan organisasi, membuat strategi untuk mencapai tujuan dan mengembangkan rencana aktivitas kerja organisasi. Perencanaan yaitu fungsi seorang manajer yang berhubungan dengan pemilihan dari sekumpulan kegiatan-kegiatan dan pemutusan tujuan-tujuan, kebijaksanaan-kebijaksanaan serta program-program yang dilakukan. Perencanaan merupakan proses terpenting dari semua fungsi manajemen karena tanpa fungsi perencanaan berjalan maka fungsi manajemen yang lainpun tidak dapat berjalan (Saladin, 2010: 20).

James E. Anderson memberikan pengertian kebijakan sebagai serangkaian tindakan yang mempunyai tujuan tertentu yang diikuti dan dilaksanakan oleh seorang pelaku atau sekelompok pelaku guna memecahkan suatu masalah tertentu (Saladin, 2010: 23). 
Edwards III dan Ira Sharkansky mengemukakan pengertian kebijakan sebagai apa yang dinyatakan dan dilakukan atau tidak dilakukan oleh pemerintah. Kebijakan dapat berupa sasaran atau tujuan dari program-program pemerintah. Penetapan kebijakan tersebut dapat secara jelas diwujudkan dalam peraturanperaturan perundang-undangan dan tindakan-tindakan yang dilakukan pemerintah ( Saladin, 2010: 24).

Selain strategi merupakan hal yang paling penting dan sangat dibutuhkan dalam menyusun suatu tindakan perencaan, pengorganisasian, pelaksanaan dan evaluasi, dibutuhkan pula kepercayaan baik dari para staff, karyawan, anggota ataupun konsumen serta yang berkaitan dengan lembaga zakat yaitu seorang muzakki.

Zakat, berarti suci, tumbuh, bertambah, dan berkah. Dengan demikian, zakat itu membersihkan (menyucikan) diri seseorang dan hartanya, pahala berambah, harta tumbuh (berkembang), dan membawa berkat. Sesudah mengeluarkan zakat seseorang telah suci (bersih) drinya dari penyakit kikir dan tamak. Hartanya juga telah bersih, karena tidak ada lagi hak orang lain pada hartanya itu. Allah berfirman, yang artinya:

"Ambillah zakat dari sebagian mereka, guna membersihkan dan menyucikan mereka, dan berdoalah untuk mereka. Sesungguhnya do'amu itu (menumbuhkan) ketentraman jiwa bagi mereka. Allah Maha Mendengar, Maha Mengetahui" (Q.S. At-Taubah, 9: 103).

(Al-Qur'an dan Terjemah, 2012. Bandung: PT SYGMA. Cet. 1)

Sabda Rasululloh SAW:

"Sedekah (zakat) itu tidak mengurangi harta, Allah akan menambah kemuliaan untuk hamba-Nya dan orang yang tunduk, tawadlu' kepada Allah akan diangkat derajatnya." (HR. Muslim). (Hasan, 2008: 15)

Secara bahasa, zakat berarti tumbuh (numumw) dan bertambah (ziyadah). Jika diucapkan, zaka al-zar', artinya adalah tanaman itu tumbuh dan bertambah. Kata zakka sering dikemukakan untuk makna thaharah (suci). Adapun zakat menurut syara', berarti hak yang wajib (dikeluarkan) dari harta. Mazhab Maliki medefinisiannya dengan, "Mengeluarkan sebagian yang khusus dari harta yang khusus pula yang telah mencapai nishab (batas kuantitas yang mewajibkan zakat) kepada orang-orang yang berhak menerimanya (mushahiqq)-nya. Dengan catatan, kepemilkan itu penuh dan mencapai hawl (setahun) buka barang tambang dan bukan pertanian." Mazhab Hanafi mendefinisikan zakat dengan, "Menjadikan sebagian harta yang khusus dari harta yang khusus sebagai milik orang yang khusus, yang ditentukan oleh syari'at karena Allah swt. "Kata "menjadikan sebagian harta sebagai milik" (tamlik) daam deinisi di atas dimaksudka sebagai penghidaran dari kata ibahah (pembolehan). (Al-Zuhayly, 1997: 82).

Kepercayaan adalah kemauan seseorang untuk bertumpu pada orang lain 
dimana kita memiliki keyakinan padanya. Kepercayaan merupakan kondisi mental yang didasarkan oleh situasi seseorang dan konteks sosialnya. Ketika seseorang mengambil suatu keputusan, ia akan lebih memilih keputusan berdasarkan pilihan dari orang-orang yang lebih dapat ia percaya dari pada yang kurang dipercayai (Moorman, 1993: 43).

Moorman, Deshpande dan Zaltman mendefinisikan kepercayaan sebagai keinginan menggantungkan diri pada mitra bertukar yang dipercayai (Zulganef, 2002: 11).

Kepercayaan sebagai kesediaan (willingness) seseorang untuk menggantungkan dirinya pada pihak lain dengan resiko tertentu (Lau dan Lee, 1999: 33) Kepercayaan terhadap merek terbentuk dari pengalaman masa lalu dan interaksi sebelumnya (Garbarino dan Johnson, 1999). Anderson dan Narus dalam Aydin dan Ozer (2005) menekankan bahwa trust terjadi ketika suatu kelompok yang lain akan memberikan hasil yang positif baginya.

Strategi dalam mendapatkan kepercayaan pada Lembaga Amil Zakat Infaq dan Shadaqah tidak terlepas dari peran serang muzakki yang menyalurkan sebagaian harta ataupun zakatnya, sehingga muzakki menjadi tolak ukur seberapa besar kesadaran masyarakat untuk berzakat dan seberapa besar tingkat kepercayaan mereka untuk menyalurkan dana zakatnya pada suatu lembaga yang dinaungi oleh pemerintahan maupun yang dibentuk secara swadaya dimana muzakki adalah seseorang yang berkewajiban untuk menunaikan zakat. (Khasanah, 2010: 37) Menurut Undang-Undang No. 38 Tahun 1999 tentang Pengelolaan Zakat pasal 1, muzakki adalah orang atau badan yang dimiliki oleh orang muslim yang berkewajiban menunaikan zakat.

\section{HASIL DAN PEMBAHASAN}

Lembaga Amil Zakat Infaq dan Shadaqah Muhammadiyah (LAZISMU) adalah lembaga zakat tingkat nasional yang berkhidmat dalam pemeberdayaan masyarakat melalui pendayagunaan secara produktif dana zakat, infaq, wakaf dan dana kedermawanan lainnya baik perseorangan, lembaga, perusahaan dan instansi lainnya.Didirikan oleh Pimpinan Pusat Muhammadiyah pada tahun 2002, selanjutnya dikukuhkan oleh Menteri Agama Republik Indonesia sebagai Lembaga Amil Zakat Nasional melalui SK No. 475/21 November 2002. Dengan telah berlakunya Undang-Undang Zakat nomor 23 tahun 2011, Peraturan Pemerintah nomor 14 tahun 2014, dan Keputusan Menteri Agama Republik Indonesia nomor 333 tahun 2015. LAZISMU sebagai lembaga amil zakat nasional telah dikukuhkan kembali melalui SK Menteri Agama Republik Indonesia nomor 730 tahun 2016.

Lembaga Amil Zakat Infaq dan Shadaqah Muhammadiyah (LAZISMU) Cabang Cibiuk merupakan lembaga nirlaba yang berada di bawah struktural Pimpinan Cabang Muhammadiyah Cibiuk yang bergerak di bidang 
penghimpunan (fundraising) dan pendayagunaan dana zakat, infaq dan shadaqah serta dana lainnya yang halal dan legal dari perorangan hal ini selaras dengan hadits yang di riwayatkan oleh Bukhari dan Muslim. (Qardawi, 2007: 376)

LAZISMU Cabang Cibiuk dibentuk dan didirikan dalam tiga periode. Periode pertama, yaitu tahun 2005-2010 yang diketuai oleh Bapak H. Usep dan berjalan hanya selama satu tahun namun belum memiliki legal formal dan baru terbentuk danmenjadi awal didirikan LAZIS. Periode kedua, yaitu pada tahun 2011-2015 pada tanggal 27 November 2011 dilakukan rapat pergantian kepengurusan dengan hasil kepengurusan LAZISMU diketuai oleh Ust. Aten, dengan SK dari Pimpinan Cabang Muhammadiyah Cibiuk Daerah Garut, secara legal formal LAZISMU Cabang Cibiuk menginduk kepada LAZIS Muhammadiyah (PP. Muhammadiyah) sebagai Badan Amil Zakat Nasional (BAZNAS) dengan Surat Keputusan (SK) Menteri Agama RI No. 457/2002 tanggal 21 November 2002, Namun secara struktural berada di bawah Pimpinan Cabang Muhammadiyah Cibiuk. Namun, meskipun demikian sudah memiliki legalitas yang formal pada periode kedua ini berjalannya kepengurusan hanya sampai satu tahun. Pada periode kedua ini para pemuda tergerak untuk menrekstrukturisasi ulang kepengurusan dikarenakan adanya anak asuh, agar lembaga yang ada bias dimanfaatkan dan terkelola dengan baik. Para pemuda berinisiatif untuk membantu pembiayaan anak asuh yang cukup besar, dikarenakan pemasukan pemuda minim (kurang) dan tidak cukup untuk membiayai anak asuh yang cukup besar dikarenakan pemasukkan pemuda kurang dan tidak cukup untuk membiayai anak asuh yang diperoleh dari kotak amal. Setelah itu para pemuda melakukan koordinasi dengan Pimpinan Cabang Muhammadiyah (PCM) dan Ketua LAZISMU pada periode ketua Ust. Aten untuk melakukan restrukturisasi ulang LAZISMU Cibiuk setelah adanya persetujuan, langsung dilakukan koordinasi pada LAZISMU Daerah kepada Pak Asep Muslim yang akhirnya menghasilkan agenda rapat restrukturisasi struktur LAZISMU Cibiuk yang bertempat di Kp. Bojongranggon dengan dihadiri Pimpinan Cabang Muhammadiyah (PCM), perwakilan disetiap ranting, dan semua jamaah. Rapat restrukturisasi struktur LAZISMU Cibiuk diperoleh hasil sebagai berikut:

Pelindung (Pimpinan Cabang Muhammadiyah Cibiuk), Penanggung Jawab (H. Endang Suryana), Ketua (Ceng Elim), Dewan Syariah (Majlis Tarjih), Sekretaris (Toni Ardi, S.Pd.I), Bendahara (Kusnadi), Tim Penggalang Dana (Isa Anshori, S.Pd.I, Cep Toni Ardi, Nandang Hermawan), Tim Distribusi (Dede Sopandi, Hendra Firmansyah, Usep Komara). Periode Ketiga, yaitu pada tahun 2016-2020 yang kini telah berjalan selama dua tahun lima bulan, pada kepemimpinan Pak Aceng Elim ini mulai mendatangkan tim ahli untuk mendapatkan pencerahan dalam menggerakkan setiap Ranting yang ada di Cabang Cibiuk untuk bias menyalurkan zakat pada LAZISMU Cibiuk, tim ahli 
yang didatangkan adalah Pak H. Dadang Syarifudin dari Pimpinan Wilayah Muhammadiyah (PWM) rapat pertama periode ketiga ini bertempat di SMAM (Sekolah Menengah Atas Muhammadiyah) Cibiuk. Kemudian, kedatangan tim ahli yang kedua bertempat di Pondok Pesantren Muhammadiyah Internasional Boarding School Cibiuk. Sehingga LAZISMU Cibiuk ini telah berjalan sebanyak III periode dan selama 12 tahun, dan berdiri karena dilatar belakangi oleh adanya Lembaga Zakat Infaq dan Shadaqah namun belum berjalan dengan optimal dan belum bisa menjadi solusi masalah sosial ekonomi terutama pada permasalah pembiayaan anak asuh.

Program-Program LAZISMU Cabang Cibiuk antara lain adalah: Pertama, paket beasiswa pendidikan, paket ini merupakan bantuan yang ditujuan untuk para siswa pelajar muslim dari keluarga kurang mampu berupa subsidi biaya pendidikan sekolah (SPP) setiap bulannya. Melalui program ini LAZISMU berupaya memberi bantuan keringanan kepada keluarga kurang mampu dalam hal memenuhi kebutuhan biaya pendidikan putra-putrinya. Kedua, gerakan orang tua asuh adalah gerakan kepedulian sosial untuk menjamin keberlangsungan pendidikan anak-anak yatim dan pelajar dari keluarga kurang mampu melalui pola pengasuhan. Bentuk program Gerakan Orang Tua Asuh adalah beasiswa dan bantuan prasarana pendidikan kepada sasaran program. Ketiga, peduli guru, sasaran dari program ini adalah para guru yang mengajar dengan sukarela di lingkup Madrasah Ibtidaiyah melalui pemberian intensif untuk guru. Keempat, Bantuan operasional Taman Pendidikan Al-Qur'an (TPQ) adalah program bantuan dana operasional rutin bagi kelancaran jalannya pengelolaan Taman Pendidikan Al-Qur'an (TPQ) tujuan dari program ini adalah untuk memberikan dukungan bagi penyelenggaraan dan pengelolaan lembaga Taman Pendidikan AlQur'an (TPQ) yang berada di Masjid/mushola sebagai sarana pendidikan dan pengajaran Al-Qur'an bagi masyarakat secara non formal. Kelima, bina mandiri wirausaha adalah program pemberdayaan ekonomimasyarakat pada kelompok binaan yang bergerak di sektor usaha mikro dan informal, seperti toko, warung, PKL, pracangan, pedagang keliling dan penjual sembako/sayur di pasar tradisional.

Tujuan dari program ini adalah sebagai pengembangan dan penguatan sektor usaha mikro. Bentuk dari program ini berupa bimbingan usaha, penyaluran pinjaman modal usaha (tanpa bunga/imbalan), pendampingan dan pengajian kelompok binaan. Keenam, Youth Entrepreneurship adalah kegiatan yang dikhususkan untuk pengembangan program Youth Entrepreneurship (YES) atau pemberdayaan kewirausahaan generasi muda dalam rangka menciptakan generasi muda yang mandiri, trampil dan kreatif. Dengan motto "Yang Muda Yang Berdaya", YES program bertujuan untuk membangun etos kewirausahaan generasi muda dalam tiga ranah strategis, yaitu : ranah kognitif, yaitu membangun mental dan spirit kewirausahaan generasi muda. Ranah afektif, 
dengan membangun kemampuan manajerial dan skill berwirausaha. Ranah psikomotorik, yakni membangun kemampuan untuk mendirikan dan mengelola usaha dengan baik. Youth Entrepreneurship program diprogram dan didesain dalam beberapa aktivitas program diantaranya : pendidikan dan pelatihan, pemagangan, pendampingan dan fasilitasi pendirian usaha hingga bantuan permodalan usaha. Ketujuh, Santunan dhuafa. Kedelapan, Santunan kesehatan masyarakat dan pemeriksaan/pengobatan kesehatan gratis. Program pelayanan kesehatan bagi masyarakat miskin dan kurang mampu yang berada di perkampungan kumuh, kawasan padat penduduk dan daerah yang terkena bencana alam. Program pelayanan kesehatan ini meliputi : layanan baksos pemeriksaan dan pengobatan gratis, layanan subsidi biaya pengobatan bagi masyarakat yang membutuhkan pengobatan ke rumah sakit atau puskesmas. Kesembilan, Muhammadiyah Tanggap Bencana (Mugana) adalah program penanggulangan bencana alam secara terpadu dan sinergis, baik nasional maupun regional, bersama Lembaga Penanggulangan Bencana hal ini selaras dengan teori (Hasbi, 2002: 8)

Muhammadiyah (MDMC) dan pihak terkait, berupa : edukasi siaga bencana alam, penghimpunan bantuan, pengiriman relawan reaksi cepat, bantuan kepada korban bencana alam. Kesepuluh, pengajian pencerah- aksi berbagi di bulan ramadhan adalah program khusus di bulan Ramadhan yang mengajak kepada ummat Islam untuk menebar kebajikan dan berbagi kebahagiaan kepada para dhuafa. Program ini meliputi : takjil on the road, buka puasa bersama anak yatim / panti asuhan yatim-piatu, bingkisan lebaran bagi dhuafa dan fii sabilillah. Kesebelas, kampung qurban untuk negeri adalah program qurban nasional yang didesain secara khusus untuk memenuhi kebutuhan masyarakat dhuafa yang berada di pedesaan, kawasan padat penduduk, perkampungan kumuh dan kantong-kantong kemiskinan dengan berpijak pada prinsip merata, adil dan fokus pada sasaran prioritas. Keduabelas, bantuan dakwah dan perlengkapan masjid (Ridho, M. T. 2008: 5).

Program yang sudah dilaksanakan adalah memberikan santunan biaya pendidikan anak yatim dan dhu'afa diantaranya : memberikan uang jajan, membayar uang syahriyah, memberikan bantuan kepada dhu'afa (pendaftaran masuk ke SMA Muhammadiyah Cibiuk). Memberikan bantuan sosial, diantaranya : memberikan bantuan kepada warga Muhammadiyah yang terkena musibah banjir. memberikan bantuan kepada warga Muhammadiyah yang terkena musibah kebakaran, memberikan bantuan kepada warga muhammadiyah yang sakit. Membeli Himpunan Putusan Tarjih (HPT) untuk dibagikan ke setiap ranting se-Cabang Cibiuk. Laporan keuangan (terlampir). Laporan pemanpaatan/penggunaan dana produktif (Pupuk).

Program yang akan dilaksanakan adalah penerbitan surat keputusan tentang penegasan 40\% $60 \%$ ke setiap ranting, bermitra dengan Majlis Tabligh 
untuk memberikan insentif kepada para mubaligh., menambah kuota anak asuh.

\section{Penyusunan Perencanaan LAZISMU Cibiuk.}

Perencanaan memiliki beberapa langkah yang harus direncanakan diantaranya yaitu menetapkan tugas dan tujuan, mengobservasi dan menganalisa, mengatakan tentang kemungkinan-kemungkinan, membuat sintesa dan menyusun. Dilakukannya penyusunan perencanaan akan mengarah pada program yang akan dilaksanakan, baik program jangka pendek, menengah ataupun jangka panjang setelah visi, misi dan tujuan ditetapkan.

Rencana yang disusun perlu disesuaikan dengan keperluan khusus di lembaga. Proses perencanaan dilakukan dengan cara pengumpulan zakat infaq dan shadaqah, yaitu dengan cara adanya program-program LAZISMU atau program-program lain seperti gerakan orang tua asuh, peduli guru, bina mandiri wirausaha, youth entreprenership, kampung qurban untuk negeri dan lain sebagainya (Wardani, 2017: 150).

Program-program yang berkaitan dengan lembaga zakat ini tentunya akan berkaitan dengan proses pendayagunaan, pengelolaan dan pendistribusian. Dalam mendayagunakan zakat, infaq dan shadaqah yang diamanahkan oleh muzakki. Diantaranya yaitu, dengan menyalurkannya kepada yang berhak dan mendayagunakannya agar berdayaguna secara jangka panjang, tentunya sesuai syari'ah dan peraturan pemerintah yang berlaku. Berikut merupakan perencanaan yang disusun oleh Lembaga Amil Zakat Infaq dan Shadaqah Muhammadiyah Cibiuk:

Pertama, Pengumpulan yang terdiri dari: Penentuan segmen dan target muzakki yaitu yang dimaksud dengan segmen dan target muzakki adalah lembaga pemerintah dan swasta seperti Bank, perusahaan-perusahaan dan individual. Dimana ketiga segmen dan target muzakki ini perlu disiapkan data yang baik. Penyiapan sumber daya dan sistem operasi, penyiapan sumber daya ini berkaiatan dengan SDM (sumber daya manusia) seperti narasumber yang kompeten dan karyawan yang handal, peningkatal LAZISMU baik kuantitas maupun kualitasnya, data dan peta zakat sebagai acuan operasional. Sedangkan penyiapan system operasi terkait dengan sosialisasi seperti kampaye melalui media masa (cetak elektronik) internet (website, blog, facebook, twitter) brosurbrosur (yang sifatnya praktis yang berisikan tentang cara perhitungannya), edukasi seperti penerbitan buku dan bulletin serta penyuluhan sadar zakat pada lembaga lainnya, konsultasi, penagihan atau penjemputan langsung dan tidak langsung (online, pay rall). Membangun sistem komunikasi dimana sistem komunikasi perlu dibangun dengan lembaga-lembaga di Pemerintahan dan swasta seperti dinas sosial, dinas pajak, DPR, dan lainnya. Serta pada lembaga keagamaan seperti MUI dan Ormas-ormas Islam. Dan individu seperti tokoh adat, tokoh masyarakat, dan para muzakki.Sistem pelayanan yang baik yang 
dimaksud dengan sistem pelayanan yang baik adalah tersedianya: Sumber daya manusia (SDM) yang STAF (shiddiq, tabligh, amanah, dan fathanah), Perkantoran yang baik, mudah dijangkau, nyaman dan layak, Alat komunikasi yang baik seperti website dan telepon, Alat transportasi yang cukup dan baik (mobil atau sepeda motor), Alat-alat administrasi lengap seperti komputer, formulir penerimaan pembayaran zakat, pemcatatan penerimaan dan pembayaran yang mudah dan transparan, Ketersediaan tempat-tempat penyetoran yang mudah dijangkau oleh muzakki.

Kedua, pengelolaan zakat sudah mengalami perkembangan yang pesat, dari yang semula bersifat tradisional beralih ke pegelolaan zakat bersifat modern.

Ketiga, pendistribusian atau penyaluran dana zakat yang dilakukan oleh LAZISMU Cibiuk disesuaikan dengan kebijakan PSAK (Pernyataan Standar Akuntansi Keuangan) 109 di bawah ini : bahwa dalam PSAK 109 disebutkan ketentuan hak amil diserahkan kepada aturan syariah dan tata kelola lembaga yang baik, presentase mustahiq diluar amil diserahkan kepada amil sesuai dengan prinsip syari'ah, kewajaran dan etika. (PSAK 109 Par 18). Penyaluran yang dilakukan oleh LAZISMU dilakukan secara benar sesuai dengan ketentuan yang berlaku, yaitu disalurkan ke delapan asnaf. Penyaluran ini dilakukan bukan sembarang menyalurkan begitu saja. Namun, ada berbagai strategi yang dilakukan agar dana yang disalurkan bergulir secara berkesinambungan dan dapat didayagunakan secara jangka panjang. Pada penyaluran ini diupayakan pengelolaan dana berorientasi untuk mengubah kaum mustahik menjadi muzakki atau mereka yang sebelumnya menerima dana zakat menjadi pemberi dana zakat (Wardani, 2017: 151-176).

Perencanaan ini mulai terbentuk dan berjalan pada periode ke III restrukturisasi pada kepemimpinan Pak Aceng Elim, serta setelah mendatangkan tim ahli dari pusat. Berdasarkan perolehan data yang saya dapatkan serta berdasarkan kondisi objektif yang terjadi di lapangan tidak semua program baik yang terlaksana ataupun belum terlaksana sudah semua terpaparkan pada observasi dan wawancara . Berikut merupakan program-program yang telah di rencanakan untuk menyalurkan dana zakat yang saya peroleh: paket beasiswa pendidikan, gerakan orang tua asuh, peduli guru, bantuan operasional taman pendidikan alqur'an (TPQ), bina mandiri wirausaha, youth entrepreneurship, santunan huafa, santunan kesehatan masyarakat dan pemeriksaan/pengobatan kesehatan gratis, muhammadiyah tanggap bencana (MUGANA), pengajian pencerah- aksi berbagi di bulan ramadhan, bantuan dakwah dan perlengkapan masjid, membeli himpunan putusan tarjih (HPT) untuk dibagikan ke setiap ranting se-cabang cibiuk, laporan keuangan (terlampir), penerbitan surat keputusan tentang penegasan 40\% $60 \%$ ke setiap ranting, bermitra dengan majlis tabligh untuk memberikan insentif kepada para mubaligh, menambah kuota anak asuh, pembentukan kordinator ranting. Dari sekian program yang terpapar masih 
terdapat program yang belum dapat terealisasikan dikarenakan hambatanhambatan serta kekurangan yang ada dimana koordinator-kordinator ranting belum berjalan secara total (Jamilah, F. 2014: 24).

\section{Pelaksanaan Penetapan Kebijakan LAZISMU Cibiuk}

Kebijakan merupakan garis pedoman untuk bertindak bagaimana sebuah organisasi Lembaga Amil Zakat Infaq dan Shadaqah Muhammadiyah Cibiuk mencapai sasaran yang diharapkan untuk meningkatkan kualitas dalam pelayanan, perecanaan, pengorganisasiaan, pengelolaan dan implementasi dilapangan. Seiring dengan perkembangan zaman yang menuntut adanyaa perubahan untuk penyesuian serta tidak terjadinya ketertinggalan diharuskan adanya penetapan kebijakan (Jamilah, F. 2014: 24).

Kebijakan yang akan ditetapkan oleh Lembaga Amil Zakat Infaq dan Shadaqah Muhammadiyah Cibiuk adalah: menetapkan koordinator lapangan pengumpulan dana zakat di setiap ranting cabang Cibiuk dimana pengumpulan dana zakat yang belum terorganisir dan terkelola dengan baik, mendorong adanya kebijakan yang baru. Dimana pemungutan dana zakat tidak langsung dilakukan oleh pengurus atau tim pengumpul dana zakat Lembaga Amil Zakat Infaq dan Shodaqoh Muhammadiyah cabang, tetapi dilakukan oleh kordinator lapangan disetiap ranting yang akan dibentuk dengan tugas mengkordinator terhimpunnya dana zakat anggota muhammadiyah yang berada di ranting. Hal ini diharapkan agar dapat mempermudah proses penghimpunan serta lebih efisien dengan permasalahan penghimpunan zakat yang menjadi penghambat dalam proses pengelolaan maupun pendistribusian dana zakat.

Dengan adanya perubahan restrukturisasi yang menghasilkan dibentuknya kordinator lapangan, maka hal ini akan membuka peluang untuk menetapkan kebijakan yang sesuai. Kordinator lapangan akan bertugas mencatat para muzakki dan mustahik sehingga pengumpulan maupun pendistribusian dapat secara cepat dijalankan dan diharapkan tepat sasaran dalam penyaluran dana zakat. Penerbitan surat keputusan tentang penegasan $40 \% 60 \%$ ke setiap ranting. Penerbitan surat keputusan 40\% 60\% ke setiap ranting ini menegaskan bahwa dari hasil pemungutan di setiap ranting yang terdiri dari 7 ranting, 60\% adalah hak ranting untuk mengelola dan mendistribusikannya dan $40 \%$ adalah hak LAZISMU cabang untuk mengelola dan mendistribusikannya atau menyalurkan dana zakat yang telah terhimpun. Dimana 60\% menjadi hak ranting dan 40\% harus di salurkan atau disetor ke cabang. Mewajibkan anggota organisasi Muhammadiyah untuk menyalurkan dana zakat ke Lembaga Amil Zakat Infaq dan Shadaqah Muhammadiyah Cibiuk. Zakat merupakan bagian terpenting yang dapat menunjang terwujudnya sistem kemasyarakatan Islam yang berdiri atas prinsip-prinsip muhammadiyah yaitu ummatan wahidan (umat yang satu), musawah (persamaan derajat, dan kewajiban), ukhuwah Islamiyah (persudaraan Islam) dan takaful ijti'ma (tanggung jawab bersama). Prinsip akan tercapai dengan adanya 
R. Cantika, A. Rahman, Herman

dorongan dari para anggota persyarikatan yang berada di bawah putusan pimpinan pusat muhammadiyah, partisipasi anggota persyarikatan menjadi alat yang sangat efektif untuk mengembangkan potensi umat.

\section{Strategi LAZISMU Cibiuk}

Strategi merupakan suatu alat atau tindakan yang digunakan oleh manajemen suatu lembaga mencapai kinerja yang konsisten dengan misi dan tujuan organisasi, yang dapat terlaksana secara keseluruhan maupun tidak. Yang meliputi perencanaan, penetapan kebijakan dan strategi sesuai dengan teori Djaslim Saladin.

Strategi di Lembaga Amil Zakat Infaq dan Shadaqah Muhammadiyah adalah realized strategic (strategi yang direalisasikan) merupakan apa yang dicapai atau apa yang telah terwujudkan. Strategik yang original itu sering mengalami perubahan dalam keseluruhan implementasinya, sesuai dengan peluang dan ancaman yang dihadapi. Dimana proses perencanaan yang terdapat dalam strategi diantaranya adalah rencana strategis sangat menentukan keberhasilan suatu lembaga, dengan pengaruh rencana bentuk komunikasi dalam menggunakan zakat maal menggunakan media online dan komunikasi tatapmuka dengan muzakki (Wardani, 2017: 151-176).

Strategik yang sebenarnya terwujudkan selalu lebih banyak atau sedikit dari pada strategik yang dikehendaki. Strategi ini tertuang pada program-program yang dikehendaki kemudian terealisasikan. Sesuai dengan keadaan di lapangan 8 program yang direalisasikan dari 12 program dari rumusan strategi yang dikehendaki melalui programnya dan 4 program yang tidak diterealisasikan, terealisasikan berdasarkan hasil penilaian dan evaluasi dimana terdapat faktor pendukung yaitu, secara geografis letak kantor pelayanan berada di dekat jalan raya Cibiuk, mempunya jejaring yang jelas, memunyai payung hukum yang jelas dan sudah mempunyai segmentasi pasar. Perbandingan ini menunjukkan bahwa keberhasilan Lembaga Amil Zakat Infaq dan Shadaqah Muhammadiyah dalam merealisasikan program-programnya (Ridho, M. T. 2008: 1).

Berikut adalah strategi yang dikehendaki berupa program yang telah dibuat oleh Lembaga Amil Zakat Infaq dan Shadaqah Muhammadiyah Cibiuk: paket beasiswa pendidikan, gerakan orang tua asuh, peduli guru/intensif guru madrasah ibtidaiyah, bantuan operasional taman pecinta al-quran (TPQ), mandiri wirausaha, youth entreprenership, santunan dhuafa, santunan kesehatan masyarakat dan pemeriksaan pengobatan kesehatan gratis, muhammadiyah tanggap bencana (MUGANA), pengajian pencerah - aksi berbagi di bulan ramadhan, kampung qurban untuk negeri, bantuan dakwah dan perlengkapan masjid. Sedangkan strategi sebenarnya/direalisasikan adalah sebagai berikut: santunan pendidikan anak yatim dan dhuafa, bantuan sosial, untuk musibah banjir, musibah kebakaran dan sakit, membeli himpunan putusan tarjih (hpt) 
untuk dibagikan pada setiap ranting se-cabang cibiuk, laporan keuangan, laporan pemanfaatan/penggunaan dana produktif (pupuk), intensif guru madrasah ibtidaiyyah, layanan jemput zakat. Kemudian strategi yang tidak terealisasi adalah: a) Terbit surat $40 \%$ dan $60 \%$, yang berisikan edaran pemberitahuan bahwa pengelolaan pengumpulan zakat yang terkumpul diranting adalah ranting sebesar 60\% dan LAZISMU 40\%, b) Intensif mubaligh, c) Menambah kuota anak asuh yang terdiri dari anak yatim, piatu dan dhuafa, d) Intensif pengurus cabang.

Dikemukakan oleh Mustafa Mansyur, bagian strategi yang paling menonjol adalah menentukan sasaran. Sasaran itu kemudian dibagi menjadi sasaran penentuan skala prioritas. (Sasono A, 1998: 242).

Hal ini yang mendasari bahwa, harus ada terlebih dahulu pencapaian yang sempit untuk mencapai hal yang luas, maka sasaran sempit menjadi prioritas utama yang harus dijalankan agar sasaran luas dapat diperoleh. Visi LAZISMU Cibiuk ini adalah Menjadi Lembaga Amil Zakat, Infaq dan Shodaqoh di Cabang Cibiuk yang amanah, transparan dan profesional dalam rangka pemberdayaan masyarakat miskin dan mustadh'afin sesuai dengan tujuan Muhammadiyah. Visi ini menggambarkan bahwa sasaran luas dari lembaga ini adalah menjadikan Lembaga Amil Zakat, Infaq dan Shodaqoh yang amanah, transparan dan professional. Sedangkan pemberdayaan masyarakat miskin dan mustadh'afin menjadi sasaran sempit. Kedua hal ini memiliki korelasi dimana untuk terwujudnya sasaran yang luas maka harus mewujudkan sasaran sempit terlebih dahulu. Namun, jika dilihat dari latar belakang didirikannya atau dibentuknya LAZISMU ini tentunya akan ditemukan ketidaksesuaian antara latar belakang pendirian dengan visi yang dibentuk. Hal demikian terjadi karena, pada perencaan pembuatan visi ini dipertimbangkan tidak hanya dari satu arah masalah sosial ekonomi saja, melainkan dilihat pula dari sisi umum permasalahan sosial ekonomi yang terlihat di Cabang Cibiuk yang terdiri dari Ranting Cibiuk Kidul, Ranting Bojongranggon, Ranting Gandayayi, Ranting Cibogo, Ranting Babakan Loa, Ranting Cikalong, Ranting Andir Majasari dan Ranting Lingkung pasir.

Dalam pencapaian penetapan sasaran ini tentunya akan dibutuhkan sumber daya manusia yang mumpuni dibidangnya yang dapat benar-benar membuat rumusan program yang akan dijalankan agar visi ini dapat tercapai dan terlaksana dengan baik. Pada penetapan sasaran yang kedua ini adalah misi. Misi akan menjadi suatu rencana jangka pendek dengan melalui langkah-langkah atau tahapan-tahapan terlebih dahulu agar visi utama dapat tercapai, serta menjadi gambaran mengapa Lembaga ZIS ini ada ditengah masyarakat. Berikut adalah misi Lembaga Amil Zakat Infaq dan Shadaqah Muhammadiyah (LAZISMU) Cibiuk, 1) Meningkatkan kesadaran ummat untuk membayar zakat sebagai salah satu rukun Islam, 2) Mengintensifkan pengumpulan ZIS pada seluruh lapisan masyarakat, 3) Mendayagunakan ZIS secara optimal untuk pemberdayaan kaum 
miskin melalui amal-amal sosial \& kemanusiaan, 4) Mengelola zakat, infaq dan shadaqah secara professional, transparan \& akuntabel. Misi ini merupakan tugas dan prinsip pokok dalam mewujudkan visi yang harus dilaksanakan agar muzakki dapat memberikan kepercayaanya dengan menyalurkan zakatnya pada lembaga yang sudah mendapatkan legal formal.penetapan misi ini sudah selaras dengan visi yang ada untuk bisa memberdayakan masyarakat, maka amil harus bisa meningkatkan kesadaran ummat untuk membayar zakat, mengintensifkan pengumpulan zakat, infaq dan shadaqah (Shodiq, 1988: 289).

Kemudian penetapan sasaran yang ketiga adalah tujuan, tujuan-tujuan yang ingin dicapai harus spesifik agar didapatkan kepastian akhir. Yang pada akhirnya tujuan LAZISMU Cibiuk adalah: Terciptanya kehidupan sosial ekonomi umat yang berkualitas sebagai benteng atas problem kemiskinan, keterbelakangan dan kebodohan pada masyarakatbawah melalui program yang dikembangkan Muhammadiyah. Strategi LAZISMU Cibiuk mengharapkan masyarakat miskin/tidak mampu kedepannya bisa hidup secara mandiri dan bisa ikut memberdayakan masyarakat lainnya agar bisa terus bersinambungan membantu menyelesaikan permasalahan sosial ekonomi yang terjadi, serta diharapkan bahwa para mustahik bisa menjadi muzakki untuk kedepannya (Ali, Mohammad Daud, 1995: 257).

\section{PENUTUP}

Perencanaan yang terdapat di LAZISMU Cibiuk terdiri dari pengumpulan, pengelolaan dan pendistribusian zakat. Pengumpulan meliputi penentuan segmen dan target muzakki, penyiapan sumber daya dan sistem operasi, membangun sistem komunikasi dan sistem pelayanan yang baik. Pengelolaan zakat dari yang semula bersifat tradisional beralih ke pegelolaan zakat bersifat modern. Pendistribusian disalurkan melalui program-program Lembaga Amil Zakat Infaq dan Shadaqah Muhammadiyah.

Kebijakan yang akan ditetapkan oleh Lembaga Amil Zakat Infaq dan Shadaqah Muhammadiyah Cibiuk adalah: 1) Menetapkan koordinator lapangan pengumpulan dana zakat di setiap ranting cabang Cibiuk. 2) Penerbitan surat keputusan tentang penegasan 40\% 60\% ke setiap ranting. 3) Mewajibkan anggota organisasi Muhammadiyah untuk menyalurkan dana zakat ke Lembaga Amil Zakat Infaq dan Shadaqah Muhammadiyah Cibiuk.

Strategi di Lembaga Amil Zakat Infaq dan Shadaqah Muhammadiyah adalah realized strategic (strategi yang direalisasikan). Strategik yang sebenarnya terwujudkan selalu lebih banyak atau sedikit dari pada strategik yang dikehendaki. Strategi ini tertuang pada program-program yang dikehendaki kemudian terealisasikan. Sesuai dengan keadaan di lapangan 8 program yang direalisasikan dari 12 program dari rumusan strategi yang dikehendaki melalui programnya dan 4 program yang tidak diterealisasikan 


\section{DAFTAR PUSTAKA}

Ali, M. D. (1995). Lembaga-lembaga Islam di Indonesia, Jakarta: PT Raja Gravindo Persada.

Al-Qur'an dan Terjemah, 2012. Bandung: PT SYGMA. Cet. 1

Al-Zuhayly, Wahbah. (1997). Zakat Kajian Berbagai Mazhab, judul asli: Al-Figh AlIslami Adillatuh, Bandung: PT Remaja Rosda Karya.

Ash-Shiddieqy, M. H. (1997). Pedoman Zakat, Semarang: PT Pustaka Rizki Putra.

David, F. (2011). Manajemen Strategis, Bandung: Salemba Empat.

Direktorat Pemberdayaan Zakat Dirjen Bimbingan Masyarakat Islam Kementrian Agama Republik Indonesia. (2009). Manajemen Pengelolaan Zakat, Jakarta.

Djamarah, Syaiful Bahri dan Zain, A. (2006). Strategi Belajar Mengajar, Jakarta: Rineka Cipta.

Gulo, W. (2008). Strategi Belajar Mengajar, Jakarta: Grasindo.

Hasan, M. (2008). Zakat dan Infaq, Salab Satu Solusi Mengatasi Problema Sosial di Indonesia, Jakarta: kencana.

Hasan, R. A. (2013). Manajemen Baitul Maal Wa Tamwil, Bandung: CV Pustaka Setia.

Jamilah, F. (2014). Strategi Penyelesaian Sengketa Bisnis, Yogyakarta: Pustaka Yustisia.

Khasanah, U. (2010). Manajemen Zakat Modern: Instrumen Pemberdayaan Ekonomi Umat, Malang: UIN-Maliki Press.

Qardawi, Y. (2007). Hukum Zakat. Terjemah: Salman Harun, dll, Jakarta: PT Pustaka Litera Antar Nusa.

Ridho, M. T. (2008). Perbedaan ZISWAF, Jakarta: Tabung Wakaf Indonesia.

Saladin, D. (2010). Manajemen Strategik, Bandung: Agung ilmu.

Sasono, A. (1998). Solusi Islam atas Problematika Umat: (Ekonomi, Pendidikan dan Dakwah), Jakarta: Gema Insani Press.

Shodiq. (1988). Kamus Istilah Agama, Jakarta: C.V. Seinttarama. Cet. 2,

Umar, H. (2001). Strategic Management in Action, Jakarta: PT Gramedia Pustaka Utama.

Wardani, Rama. " Strategi Komunikasi Badan Amil Zakat Nasional dalam Pengumpulan Zakat Maal." Ilmu Dakwah: Academic Journal for Homiletic 
R. Cantika, A. Rahman, Herman

Studies [Online], 11.1 (2017): 151-176. Web. 2 Sep. 2018 